\title{
Corps matériel, pensée chamanique et modernité chez les Yanomami
}

Jean Chiappino

\section{(2) OpenEdition}

Édition électronique

URL : https://journals.openedition.org/tc/512

DOI : $10.4000 /$ tc. 512

ISSN : 1952-420X

Éditeur

Éditions de l'EHESS

\section{Édition imprimée}

Date de publication : 1 mars 1996

ISSN : 0248-6016

\section{Référence électronique}

Jean Chiappino, "Corps matériel, pensée chamanique et modernité chez les Yanomami », Techniques \& Culture [En ligne], 25-26 | 1996, mis en ligne le 28 octobre 2005, consulté le 29 septembre 2022.

URL : http://journals.openedition.org/tc/512 ; DOI : https://doi.org/10.4000/tc.512

Ce document a été généré automatiquement le 29 septembre 2022.

Tous droits réservés 


\section{Corps matériel, pensée chamanique et modernité chez les Yanomami}

Jean Chiappino 